\title{
Does Housework Help Improve Academic Performance? An Empirical Analysis on the Influence of Participation in Housework on Academic Performance of Primary and Middle School Students
}

\author{
Xuechun Wang, ${ }^{1}$ Jijun Yao, ${ }^{1}$ Shike Zhou ${ }^{2}$ \\ 1. Nanjing Normal University, Nanjing 210004, China \\ 2. Jiangsu Academy of Educational Sciences, Nanjing 210024, China
}

\begin{abstract}
At present, even if the education on hard-working spirit has been emphasized increasingly as an important part of practical education in China's education policy, the reality is still far from satisfactory, because many parents do not provide their children with sufficient opportunities to do housework. Previous studies have indicated that the empirical analysis remains to be improved in terms of the relationship between housework and the development of primary and junior high school students. Based on data from the 2020 Monitoring of Students' Academic Quality in Basic Education in Jiangsu Province Study, this study investigates the influence of primary and secondary school students' participation in housework on academic performance by using OLS regression and Coarsened Exact Matching (CEM). The results show that the current proportion of primary and junior high school students involved in housework is not high; however, participating in housework frequently will positively affect the academic performance of primary and junior high school students. Participation in housework in primary school has a greater positive impact on academic performance than that in junior high school. In addition, since excessive academic burden is the main factor hindering primary and junior high school students from being involved in housework, it is necessary to strengthen the publicity of education on hard-working spirit to help people know its importance. Also, we suggest the burden on schoolwork should be reduced to in order to promote more diversified housework related educational opportunities for students.
\end{abstract}


Doi: 10.15354/bece.22.or009.

How to Cite: Wang, X., Yao, J., \& Zhou, S. (2022). Does housework help improve academic performance? An empirical analysis on the influence of participation in housework on academic performance of primary and middle school students. Best Evidence in Chinese Education, 10(1):1283-1301.

Keywords: Participation in Housework, Education on Hard-Working Spirit, Student Academic Achievement, Coarsened Exact Matching, Reducing Burden and Increasing Efficiency

\footnotetext{
About Authors: Xuechun Wang, School of Educational Science, Nanjing Normal University, 122 Ninghai Road, Nanjing 210024, China, E-mail: wxc3a@qq.com

Shike Zhou, Educational Measurement and Evaluation, Jiangsu Academy of Educational sciences, China. E-mail: jyszsk@163.com

Correspondence to: Jijun Yao, School of Educational Science, Nanjing Normal University, 122 Ninghai Road, Nanjing 210024, China, E-mail: yaojijun njnu@163.com

Funding: Jiangsu University Advantage Discipline Construction Project Funding Project (PAPD)

Conflict of Interests: None.
}

(c) 2022 Insights Publisher. All rights reserved.

(c) (7) (-) Creative Commons Non Commercial CC BY-NC: This article is distributed under the terms of the Creative Commons Attribution-NonCommercial 4.0 License

(http://www.creativecommons.org/licenses/by-nc/4.0/) which permits non-commercial use, reproduction and distribution of the work without further permission provided the original work is attributed by the Insights Publisher. 


\section{Introduction}

$\mathrm{E}$

NCOURAGING students to perform housework fits well with the goals of China's education. But does time spent on housework limit students' study time, thus being harmful to academic achievement? Chinese education policy has long emphasized "learning from practice", and housework is an important form of rigorous work. Whereas the existing nature of Chinese education requires students to perform mountains of homework, parents tend to protect their children from household work so that they may have more time for academic study. This paper addresses this issue by examining the meaning of housework education, and the effects of housework performance on student academic achievement.

In China, the significance of housework education was early recognized and has been supported by policies promoting a spirit of hard work, an important domain of the great Chinese educator Cai Yuanpei's "Educating Five Domains Simultaneously" (Tang, 2009). These five domains are: Military national education (focusing on the cultivation of the five martial ethics of wisdom, faith, benevolence, courage, and strictness); Materialistic education (advocating a close relationship between education and national economic life); Civic Moral education (advocating love for the motherland and its people, love of labor, love of science, and care for public property); Worldview education (forming students' correct positions, viewpoints, and methods), Aesthetic education (training students' ability to recognize, love, and create beauty), Meanwhile, at the beginning of the founding of New China, the Common Program of the Chinese People's Political Consultative Conference listed "love of labor" as one of the "five national merits." In 1950, Junrui Qian, Vice Minister of Education, clearly pointed out in the Guidelines for Current Educational Construction that the central policy of the New Democratic Education was to serve workers and peasants and develop production and construction (He, 2009). Since then, with education for hard-working spirit being raised to unprecedented new heights on the political, economic and epistemological range, teaching children how to perform housework has been gradually incorporated into the school's formal teaching plan (Lao, 1998), and has become an important way to shape students' character and the key to their all-round development (Li \& Qu, 2018). Since the reform and opening up, the political connotation of education for hard-working spirit has been weakened, but is still considered an essential way to educate people. In recent years, the authorities at all levels have issued a series of policy documents to highlight the role of education on hard-working spirit. In March and July 2020, the Central Committee of the Communist Party of China, the State Council and the Ministry of Education respectively issued the Opinions on Comprehensively Strengthening Labor Education in Colleges, Primary and Junior High Schools in the New Era (hereafter referred to as the "Opinions") and The Guidelines for Labor Education in Colleges and Universities (Hereafter referred to as the "Outline"), the status of education for the hard-working spirit has been pushed to new levels.

In sharp contrast with this policy emphasis, however, the current situation of housework education is not satisfactory. For instance, Wang and Xu (2020) conducted questionnaire surveys and on-site interviews with 4,224 students in 6 provinces and cities in the east, central and west part of China. Only $6.6 \%$ of the basic education schools set up housework courses, and the higher the school level, the lower the devel- 
opment of housework education as well as the satisfaction of students with participation in housework. The proportion of students who never participate in housework in primary school, junior high school and high school accounted for $13.8 \%, 26.7 \%$ and $41.7 \%$ respectively (Wang \& Xu, 2020). Bao (2013) found that although $83.1 \%$ of parents are aware of the necessity of letting their children participate in housework, only $41.8 \%$ of them would really require their children to perform it (Bao, 2013). In many cases, apart from "spoiling" their children, the reason parents are reluctant to allow their children to participate more in housework is that they pay more attention to their children's academic performance. To that end, many parents tend to impose greater academic stress on their children through various means (Goh \& Kuczynski, 2014). Spare time of young people in China will thus be spent on extracurricular activities, with only limited time devoted to practical educational activities, let alone autonomously planned activity (Wang \& Chen, 2015). Changing this situation will likely ensure the implementation of relevant policies and more supportive guidance. Moreover, one question that parents are generally concerned about needs to be answered: Will housework affect children's academic performance?

\section{Literature Review}

In fact, the academic circle has long been involved in the issue of housework and youth development. Embodied cognition theory suggests that the body, brain, and environment are unified. This in turn suggests that significant physical activity can improve learning experiences and academic performance (Wang \& Ye, 2018). Studies underscore this conclusion with respect to language learning (Lan, Chen \& Li, et al., 2015; Mcclelland, Pitt \& Stein, 2015; Su \& Ye, 2013) and mathematics learning (Ruiter, Loyens \& Paas, 2015; Smith, King \& Hoyte J, 2014). Marx believed that hard work satisfies the needs of individual survival and contained the main force for helping mankind overcome difficulties and nature. In the process of doing housework, human spiritual development is closely linked with education for hard-working spirit (Huang, 2004), which is identified by some far-reaching empirical studies. In 1989, Jacqueline J. Goodnow, a senior professor in the Faculty of Behavioral Sciences at Macquarie University in Australia, interviewed 45 mothers with children aged 9-11 and found that in addition to cultivating children's sense of responsibility, participation in housework played a vital role in children's socialization, and that different ways of distributing housework had different effects on family relations (Goodnow, 1989). Harvard University professor Robert Waldinger in his 20-year Grant Study argued that people who had housework experience in childhood, even simple housework experience, tended to have more happiness in future life than those without housework experience (George, 2012). Because of this, many countries attach great importance to children's housework and have developed education on hard working spirit methods with various cultural characteristics (Li, 1983; Gu, 2018; Fu \& Zhou, 2005; Tan, 2019). Relevant studies have indicated that frequent participation in housework is not only conducive to the improvement of students' academic performance, but also has a positive impact on the development of children's character, habits and non-cognitive abilities. In contrast, lack of housework may bring about many negative effects such as arrogance, laziness, cognitive bias, etc. (Gu, 2021). However, many foreign studies have suggested that in families with 
low economic background, housework may not have a positive effect on the growth of children, and have the possibility of making children become "child laborers". In 1990, based on data from the National Household and Household Survey Sampson Lee Blair, a professor in the Department of Sociology at the University of Oklahoma, conducted a series of surveys on children involved in domestic labor under different circumstances and claimed that children in "dual-career families" are especially likely to be more and more served as a source of "alternative labor," which would not only reduce the differences between the role of adults and children in the family, but also have a negative impact on children's happiness and growth (Blair, 1992).

So far, most domestic housework education research is based on theoretical discussions, most of which have focused on the impact of housework education on students' developments and the ways to strengthen and encourage its performance (Chen \& Lu, 2021; Xiong, 2021; Yuan \& Li, 2021; Yin, 2021). Despite a few rigorous empirical studies, many improvements can be made in terms of data quality, method application, and robustness of conclusions to provide greater support for policies aimed at improving housework education. Our research, therefore, provides more complete empirical analysis aimed at answering the following questions. Firstly, what is the current status of primary and junior high school students in housework? Secondly, how does participation in housework affect the academic performance of primary and junior high school students? Thirdly, what are the factors that influence primary and junior high school students to participate in housework? Finally, a discussion will be given to investigate what measures should be taken to drive primary and junior high school students to participate in housework to promote their overall development.

\section{Research Design and Methods}

\section{Data Source and Sample Description}

This study selects data from the 2020 Monitoring of Students' Academic Quality in Basic Education in Jiangsu Province, which is implemented every two years. The subjects of the 2020 test were students in the fifth and ninth grades. In addition to an academic test, the survey collects relevant information about school leaders, teachers, parents, and students through questionnaires. Through two-stage stratified sampling, the 2020 survey includes a total of 214,205 fifth-grade students and 147,805 ninth-grade students, a sufficient data source for this study. To ensure the data validity, cases that failed to provide important information or that had obvious response abnormalities were eliminated. Our resulting subsample contains 103,507 primary school and 100,998 junior high school students.

\section{Variable Selection and Description}

The variables of this study are described in Table 1 .

\section{The Dependent Variable}




\section{Table 1. Variable Description.}

\begin{tabular}{|c|c|c|c|}
\hline Variable Name & Variable Type & Data Type & Variable Description \\
\hline $\begin{array}{l}\text { Housework } \\
\text { Participation } \\
\text { Frequency }\end{array}$ & $\begin{array}{l}\text { Core } \\
\text { Explanatory } \\
\text { variables }\end{array}$ & $\begin{array}{l}\text { Dichotomous } \\
\text { variables }\end{array}$ & Infrequent=0; Regular $=1$ \\
\hline Gender & \multirow[t]{12}{*}{$\begin{array}{l}\text { Control } \\
\text { variable }\end{array}$} & $\begin{array}{l}\text { Dichotomous } \\
\text { variables }\end{array}$ & Male $=1 ;$ Female $=0$ \\
\hline Only-Child & & $\begin{array}{l}\text { Dichotomous } \\
\text { variables }\end{array}$ & Only child $=1$; Non-only child $=0$ \\
\hline $\begin{array}{l}\text { Urban/ } \\
\text { Rural Area }\end{array}$ & & $\begin{array}{l}\text { Dichotomous } \\
\text { variables }\end{array}$ & City $=1 ;$ Countryside $=0$ \\
\hline $\begin{array}{l}\text { Father's } \\
\text { Education }\end{array}$ & & $\begin{array}{l}\text { Continuous } \\
\text { variable }\end{array}$ & \multirow{2}{*}{$\begin{array}{l}\text { Junior high school and below=9 years; High school (vocational high } \\
\text { school, Technical secondary school or technical school)=12; Uni- } \\
\text { versity=16 years; Postgraduate and above }=19\end{array}$} \\
\hline $\begin{array}{l}\text { Mother's } \\
\text { Education }\end{array}$ & & $\begin{array}{l}\text { Continuous } \\
\text { variable }\end{array}$ & \\
\hline $\begin{array}{l}\text { Father's } \\
\text { Occupation }\end{array}$ & & $\begin{array}{l}\text { Continuous } \\
\text { variable }\end{array}$ & \multirow[b]{2}{*}{ Assign expert values to different occupations } \\
\hline $\begin{array}{l}\text { Mother's } \\
\text { Occupation }\end{array}$ & & $\begin{array}{l}\text { Continuous } \\
\text { variable }\end{array}$ & \\
\hline $\begin{array}{l}\text { Family's } \\
\text { Economic Status }\end{array}$ & & $\begin{array}{l}\text { Continuous } \\
\text { variable }\end{array}$ & Standardized score of household economic situation \\
\hline $\begin{array}{l}\text { Central Region } \\
\text { of Jiangsu }\end{array}$ & & $\begin{array}{l}\text { Dummy varia- } \\
\text { ble }\end{array}$ & Central Region of Jiangsu=1; Others $=0$ \\
\hline $\begin{array}{l}\text { Southern } \\
\text { Region of } \\
\text { Jiangsu }\end{array}$ & & $\begin{array}{l}\text { Dummy varia- } \\
\text { ble }\end{array}$ & Southern region of Jiangsu $=1 ;$ Others $=0$ \\
\hline $\begin{array}{l}\text { Student's } \\
\text { Residence }\end{array}$ & & $\begin{array}{l}\text { Dichotomous } \\
\text { variables }\end{array}$ & On campus $=1 ; \quad$ Off campus $=0$ \\
\hline $\begin{array}{l}\text { Academic } \\
\text { Burden }\end{array}$ & & $\begin{array}{l}\text { Continuous } \\
\text { variable }\end{array}$ & $\begin{array}{l}\text { The sum of the time on homework and the time on supplementary } \\
\text { lessons }\end{array}$ \\
\hline $\begin{array}{l}\text { Academic } \\
\text { Performance } \\
\text { (Total) }\end{array}$ & $\begin{array}{l}\text { Explained } \\
\text { variable }\end{array}$ & $\begin{array}{l}\text { Continuous } \\
\text { variable }\end{array}$ & $\begin{array}{l}\text { Primary school: the average score of total scores in Chinese, math- } \\
\text { ematics, and English; Junior high school students: the average } \\
\text { score of total scores in Chinese, mathematics, English, physics, } \\
\text { chemistry, and biology. }\end{array}$ \\
\hline
\end{tabular}

The dependent variable of this study is the student's academic performance. Primary school test scores include three subjects: Chinese, mathematics, and English, while junior high school test scores include six subjects: Chinese, mathematics, English, physics, chemistry, and biology. In processing the original scores, we used Multiple Imputation (MI) to estimate missing item values. The Raida criterion will assume that a set of test data only contains random errors, then calculate and process them to obtain the standard deviation, and determine an interval with a certain probability. It is believed that any error exceeding this interval is not a random error but a gross error, which should be eliminated (Zhang \& Yuan, 1997). Finally, the mean value of the multiple interpolation results is calculated to obtain the final result of the interpolation.

\section{Core Independent Variables}

In this provincial survey, students were asked "How often did you do housework in the last month?" Their responses were measured on a four-point scale ranging from "never" to "always." Items were ranked on a scale, ranging from "Never", "Occasionally", "Very often", to "Always". Because we planned to adopt a matching method to eliminate the influence of sample selection bias and improve the accuracy of analysis, we recoded this item into a dichotomous variable for which responses of "Never" and "Occasionally" were treated as never doing housework and responses of "Occasionally" and 
Table 2. Descriptive Statistics for Variables.

\begin{tabular}{lllllll} 
& \multicolumn{2}{l}{ Primary School } & \multicolumn{2}{l}{ Junior High School } & \multirow{2}{*}{ Min } & \multirow{2}{*}{ Max } \\
\cline { 2 - 5 } & Mean & SD & Mean & SD & & 1 \\
\hline Housework Participation Freq. & 0.769 & 0.422 & 0.463 & 0.499 & 0 & 1 \\
\hline Gender & 0.519 & 0.500 & 0.518 & 0.500 & 0 & 1 \\
\hline Only-Child & 0.369 & 0.483 & 0.466 & 0.499 & 0 & 1 \\
\hline Urban/Rural Area & 0.704 & 0.457 & 0.703 & 0.457 & 0 & 19 \\
\hline Father's Education & 12.987 & 3.232 & 11.678 & 2.854 & 9 & 19 \\
\hline Mother's Education & 13.164 & 3.334 & 11.359 & 2.795 & 9 & 69 \\
\hline Father's Occupation & 44.311 & 20.800 & 38.874 & 19.672 & 0 & 69 \\
\hline Mother's Occupation & 34.515 & 23.867 & 30.831 & 21.209 & 0 & 1 \\
\hline Family's Economic Status & 0.422 & 0.137 & 0.428 & 0.130 & 0 & 1 \\
\hline Central Region of Jiangsu & 0.165 & 0.371 & 0.161 & 0.368 & 0 & 1 \\
\hline Southern Region of Jiangsu & 0.588 & 0.492 & 0.575 & 0.494 & 0 & 1 \\
\hline On/Off Campus & 0.031 & 0.172 & 0.140 & 0.346 & 0 & 9 \\
\hline Academic Burden & 3.107 & 1.871 & 4.008 & 2.029 & 0 & $684.220 / 691.630$ \\
\hline Academic Performance (Total) & 519.083 & 53.088 & 512.708 & 59.704 & $265.900 / 276.210$ & \\
\hline
\end{tabular}

"Always" were treated as always doing so. This allowed intervention and control groups to be constructed and analyzed with the matching method.

\section{Control Variables}

Variables were included to control for salient student characteristics such as gender, family background, academic burden, residence (on/off campus), and urbanicity. Student family background was estimated based on five variables: father's education level, mother's education level, father's occupation, mother's occupation, and family economic status. Parent education was assigned a value of 1 for junior high or lower, 2 for high school, 3 for university degree, and 4 for post graduate degree. (Regression treats 9, 12, 16, and 19 the same as 1, 2, 3, and 4.) In terms of parent occupations, we refer to the research of Li Chunling, Lu Xueyi, etc., (2005) and use the expert assignment method to assign values to the parents' occupations using professional reputation scores. The specific method ranks the professional prestige of various occupations on a zero to 100 scale. The values in our subsample range from zero to 69 . As for family economic status, the family economic conditions are characterized by investigating the amount of family possessions. Taking into account the differences between urban and rural areas, we also include dummy variables of urban and rural areas in the model.

Table 2 reports descriptive statistics for the variables in this study. The table indicates that the proportion of primary students who often participate in housework in the sample is $76.9 \%$, and the proportion of junior high school students who often participate in housework is $46.3 \%$. The average academic burden of junior high school students is 4 hours, while for primary school students, it is 3 hours. The average academic scores of primary and junior high school students were 519.08 and 512.71 respectively. 


\section{Model Setting}

This research aims to explore the extent to which the frequency of participation in housework can affect students' academic achievement. But because characteristics such as family economic background can affect the analysis results or lead to biased estimates, matching methods are used to eliminate sample selection bias to solve this problem. However, since the commonly used Propensity Score Matching (PSM) has to pass the balance test and the common support domain test, it has higher requirements on the data and often fails to match (Rosenbaum \& Rubin, 1983). As far as this study is concerned, the pre-phase analysis indicated that it was impossible to use the PSM method to eliminate possible sample selection bias because it failed to pass the relevant test.

In response to this problem, we use the Coarsened Exact matching (CEM) method to improve the accuracy of the analysis. CEM's essence is to control the difference between the treatment group and the control group before treatment by matching samples, so that the covariate empirical distribution of the treatment group and the control group are closer. When using the CEM method, the maximum imbalance between the treatment group and the control group can be selected by the researcher in advance, and the variables are grouped according to the researcher's criteria. As such, while retaining basic information, the efficiency of matching is improved, and both the degree of model dependence and the estimation error of average treatment effect are reduced. In this way, the data can be limited within the scope of common support, which conforms to the principle of consistency and is less sensitive to measurement errors. This method has a very important feature, that is, monotonic imbalance boundary, which means based on the criteria for grouping variables in advance, it can ensure matching to improve the balance of the sample, and thus limit the degree of model dependence and the estimation error of average treatment effect. So there is no need to check the balance of covariates after matching, and adjusting the imbalance of one variable will not affect the imbalance of any other variables. CEM can yield a weight variable (Weight) during the matching process without requiring the two groups before and after the matching to be numerically equal. Using CEM can solve sample selection bias while retaining the original samples to the greatest extent, and improve the accuracy of the model for the analysis. (Iacus et al., 2011; Chen \& Gu, 2019)

Therefore, this study calculates the weights (cem_weights) through the panexact matching method, and includes them in the regression model, so as to control selection bias and reduce the imbalance of feature variables between groups. The characteristic variables used for Coarsened Exact matching are gender, only-child, urban/rural area, parents' maximum years of education, parents' occupational prestige, family economic background level, on/off campus, and student's academic burden. The specific model is shown in equation (1), where AveGradesi is the average academic performance score of the $\mathrm{i}$-th student, $\beta 0$ is the intercept of the model, Lao2 $\mathrm{i}$ is whether the $\mathrm{i}$ th student often participates in housework, and $\mathrm{Xi}$ is the control variable. $\beta 1$ and $\beta 2$ are the regression coefficients of each variable, and $\varepsilon i$ is the residual.

$$
\text { AveGrades }=\beta_{0}+\beta_{1} \text { Lao }_{\mathrm{i}}+\beta_{2} X_{\mathrm{i}}+\varepsilon_{\mathrm{i}}[\text { cem_weights }]
$$


Table 3. Least Squares Regression Results (Dependent Variable: Academic Performance).

\begin{tabular}{|c|c|c|c|c|c|c|c|c|}
\hline \multirow{2}{*}{ Variable } & \multicolumn{2}{|l|}{ Model 1} & \multicolumn{2}{|l|}{ Model 2} & \multicolumn{2}{|l|}{ Model 3} & \multicolumn{2}{|l|}{ Model 4} \\
\hline & PS & JHS & PS & JHS & PS & JHS & PS & JHS \\
\hline \multirow{2}{*}{$\begin{array}{l}\text { Housework } \\
\text { Participation } \\
\text { Freq. }\end{array}$} & $12.381^{* \star *}$ & $-6.653^{\star \star \star}$ & $12.546^{\star \star \star}$ & $-3.103^{\star \star \star}$ & $11.196^{\star \star \star}$ & $-1.327^{* \star \star}$ & $12.446^{\star * *}$ & $-0.777^{* *}$ \\
\hline & $(0.414)$ & $(0.376)$ & $(0.399)$ & $(0.382)$ & $(0.390)$ & $(0.372)$ & $(0.393)$ & $(0.372)$ \\
\hline \multirow{2}{*}{ Gender } & & & $-6.911^{\star * *}$ & $-10.089^{* * *}$ & $-5.465^{\star \star \star}$ & $-8.289^{* * *}$ & $-5.114^{\star \star \star}$ & $-7.902^{* \star *}$ \\
\hline & & & $(0.317)$ & $(0.377)$ & $(0.311)$ & $(0.367)$ & $(0.313)$ & $(0.365)$ \\
\hline \multirow{2}{*}{ Only-Child } & & & $22.299^{* * *}$ & $16.714^{* \star *}$ & $18.284^{\star \star *}$ & $9.302^{\star \star *}$ & $17.390^{* * *}$ & $9.605^{\star \star \star}$ \\
\hline & & & $(0.328)$ & $(0.388)$ & $(0.327)$ & $(0.389)$ & $(0.329)$ & $(0.388)$ \\
\hline \multirow{2}{*}{$\begin{array}{l}\text { Urban/ } \\
\text { Rural Area }\end{array}$} & & & $16.249^{\star \star \star}$ & $16.559^{\star \star *}$ & $9.828^{* * *}$ & $7.800^{\star \star *}$ & $8.156^{\star \star \star}$ & $6.168^{\star \star \star}$ \\
\hline & & & $(0.367)$ & $(0.421)$ & $(0.374)$ & $(0.428)$ & $(0.381)$ & $(0.438)$ \\
\hline \multirow{2}{*}{$\begin{array}{l}\text { Central Region } \\
\text { of Jiangsu }\end{array}$} & & & $20.025^{\star \star \star}$ & $4.225^{\star \star *}$ & $16.573^{\star \star *}$ & $3.138^{\star \star \star}$ & $15.869^{\star \star *}$ & $4.932^{\star \star \star}$ \\
\hline & & & $(0.525)$ & $(0.607)$ & $(0.522)$ & $(0.594)$ & $(0.528)$ & $(0.614)$ \\
\hline \multirow{2}{*}{$\begin{array}{l}\text { Southern } \\
\text { Region of } \\
\text { Jiangsu }\end{array}$} & & & $12.982^{* * *}$ & $3.246^{* * *}$ & $8.224^{* * *}$ & $(0.246)$ & $6.592^{* * *}$ & $-1.080^{* *}$ \\
\hline & & & $(0.413)$ & $(0.469)$ & $(0.409)$ & $(0.463)$ & $(0.413)$ & $(0.489)$ \\
\hline \multirow{2}{*}{$\begin{array}{l}\text { Father's } \\
\text { Education }\end{array}$} & & & & & $4.259^{\star * *}$ & $4.765^{\star \star \star}$ & $4.089^{* * *}$ & $4.659^{\star \star \star}$ \\
\hline & & & & & $(0.075)$ & $(0.097)$ & $(0.075)$ & $(0.097)$ \\
\hline \multirow{2}{*}{$\begin{array}{l}\text { Mother's } \\
\text { Education }\end{array}$} & & & & & $-1.626^{\star * *}$ & $0.641^{\star * *}$ & $-1.650^{\star \star *}$ & $0.554^{\star \star \star}$ \\
\hline & & & & & $(0.072)$ & $(0.102)$ & $(0.073)$ & $(0.101)$ \\
\hline \multirow{2}{*}{$\begin{array}{l}\text { Father's } \\
\text { Occupation }\end{array}$} & & & & & $0.034^{\star * *}$ & $0.071^{\star * *}$ & $0.017^{*}$ & $0.066^{\star \star \star}$ \\
\hline & & & & & $(0.009)$ & $(0.012)$ & $(0.009)$ & $(0.012)$ \\
\hline \multirow{2}{*}{$\begin{array}{l}\text { Mother's } \\
\text { Occupation }\end{array}$} & & & & & $0.086^{\star * \star}$ & $0.104^{\star \star *}$ & $0.078^{* * *}$ & $0.079^{\star \star \star}$ \\
\hline & & & & & $(0.008)$ & $(0.010)$ & $(0.008)$ & $(0.010)$ \\
\hline \multirow{2}{*}{$\begin{array}{l}\text { Family's } \\
\text { Economic } \\
\text { Status }\end{array}$} & & & & & $67.842^{\star \star *}$ & $47.598^{* * *}$ & $62.050^{* * *}$ & $42.534^{* * *}$ \\
\hline & & & & & (1.328) & (1.659) & (1.351) & (1.662) \\
\hline \multirow{2}{*}{$\begin{array}{l}\text { On/Off } \\
\text { Campus }\end{array}$} & & & & & & & $-18.254^{\star \star \star}$ & $9.412^{\star \star \star}$ \\
\hline & & & & & & & $(1.078)$ & $(0.614)$ \\
\hline \multirow{2}{*}{$\begin{array}{l}\text { Academic } \\
\text { Burden }\end{array}$} & & & & & & & $2.957^{\star * \star}$ & $3.162^{\star \star \star}$ \\
\hline & & & & & & & $(0.092)$ & $(0.100)$ \\
\hline \multirow{2}{*}{ Constant } & 509.563 & $\begin{array}{l}515.789 \\
\star \star \star\end{array}$ & $\begin{array}{l}483.359 \\
\star \star \star\end{array}$ & $\begin{array}{l}498.413 \\
\star \star \star\end{array}$ & $\begin{array}{l}426.728 \\
\star \star \star\end{array}$ & $\begin{array}{l}419.638 \\
\star \star \star\end{array}$ & $\begin{array}{l}425.482 \\
\star \star \star\end{array}$ & $\begin{array}{l}411.846 \\
\star \star \star\end{array}$ \\
\hline & $(0.372)$ & $(0.257)$ & $(0.554)$ & $(0.534)$ & $(0.878)$ & $(1.002)$ & $(0.887)$ & $(1.039)$ \\
\hline Sample Size & 103507 & 100,998 & 98,130 & 95,719 & 88,805 & 89,426 & 86,454 & 88,848 \\
\hline Adjusted $\mathrm{R}^{2}$ & 0.010 & 0.003 & 0.11 & 0.05 & 0.209 & 0.154 & 0.222 & 0.165 \\
\hline $\mathrm{F}$ & 895.55 & 313.24 & $1,955.68$ & 865.05 & 2053.55 & 1565.6 & 1831.57 & 1422.80 \\
\hline
\end{tabular}

\section{Regression Results}

\section{OLS Regression Results}


This research first uses the least squares regression to obtain a benchmark estimate of the impact of students' participation in housework on their academic achievement. The results in Table 3 show that after controlling students' personal characteristics, family background, residency (on/off campus), and the burden of schoolwork, a significant positive correlation exists among primary school students between housework participation and academic performance. Among junior high students, however, this relationship is significant negative. Instead, there is a significant positive correlation among junior high students between mother's schooling years, on/off campus residency, the burden of schoolwork, and academic performance. It can be seen from Model 4 that compared with the pupils who do not often participate in housework; pupils with frequent housework participation score an average of 12.45 points higher in academic performance. From Model 3 and Model 4, it is found that the father's education level, parents' professional background, and family economic background, all have a significant positive impact on children's academic performance in both elementary and junior high school and family economic background factors have the greatest impact. It is worth noting that although the mother's education level has a significant impact on primary and junior high school students, its direction on primary school students' academic performance is negative, that is, mother's high educational background is not conducive to the improvement of the primary and junior high school students' academic performance.

\section{Regression Results after Controlling the Selection Bias}

Because of the influence of sample selection bias, the results of the benchmark regression may have biased estimates. Therefore, this study uses Coarsened Exact matching technology to improve the estimation accuracy of the model. The L1 value (Multivariate Imbalance Measure) generated by the Coarsened Exact matching indicates the degree of imbalance of the data. L1 ranges from 0 to 1 , with larger values indicating greater imbalance. Researchers can judge the matching effect according to the changes in L1 value. The more L1 drops, the better the matching effect (Iacus, et al., 2012).

Table 4 shows that after Coarsened Exact matching, 24,117 cases from the primary school sample remained valid as did 43,514 cases from the junior high sample, accounting for $23.3 \%$ and $43.1 \%$ of the original samples respectively. The L1 value decreased from 0.87 and 0.67 to 0.52 and 0.34 , respectively. This shows that while obtaining a better matching effect, more samples are retained in the study (see Table 4). The obtained weights (cem_weights) are brought into the regression model for calculation, and the regression results are shown in Table 5.

After controlling sample selection bias, doing housework frequently still has a significant positive impact on academic performance among primary school students. While for junior high school students, the correlation between participating in the physical housework frequently and academic performance has changed from negative to positive. Specifically, in the explained variable of student academic performance, the differences caused by other control variables that affect whether students often participate in housework dropped by 1-2 points, indicating that the Coarsened Exact matching technique has corrected the biased estimate of least squares method well. Of particular interest, the regression coefficient of primary school students' academic performance and the frequency of participation in housework become 12.18, while that of junior high 
Table 4. Coarsened Exact Matching Results (Dependent Variable: Academic Performance).

\begin{tabular}{|c|c|c|c|c|c|c|}
\hline & \multicolumn{3}{|l|}{ Primary School } & \multicolumn{3}{|c|}{ Junior High School } \\
\hline & $\begin{array}{l}\text { Infrequently } \\
\text { Participate } \\
\text { In Housework }\end{array}$ & $\begin{array}{l}\text { Frequently } \\
\text { Participate } \\
\text { In Housework }\end{array}$ & Total & $\begin{array}{l}\text { Infrequently } \\
\text { Participate } \\
\text { In Housework }\end{array}$ & $\begin{array}{l}\text { Frequently } \\
\text { Participate } \\
\text { In Housework }\end{array}$ & Total \\
\hline $\begin{array}{l}\text { Total } \\
\text { Sample }\end{array}$ & 23,917 & 79,590 & 103,507 & 54,224 & 46,774 & 100,998 \\
\hline $\begin{array}{l}\text { Matched } \\
\text { Sample }\end{array}$ & 8,097 & 16,020 & 24,117 & 22,504 & 21,010 & 43,514 \\
\hline $\begin{array}{l}\text { Unmatched } \\
\text { Sample }\end{array}$ & 15,820 & 63,570 & 79,390 & 31,720 & 25,764 & 57,484 \\
\hline $\begin{array}{l}\text { Before } \\
\text { Matching L1 }\end{array}$ & 0.87 & & & 0.67 & & \\
\hline $\begin{array}{l}\text { After } \\
\text { Matching L1 }\end{array}$ & 0.52 & & & 0.34 & & \\
\hline
\end{tabular}

school students is 1.27 .

Among the control variables, for both primary school and junior high school students, girls, only-children, and students from urban area have higher academic performance scores than boys, non-only children, and students from rural area. Regional factors and living on or off campus have different effects on elementary school students and junior high school students. The former only significantly predicts the academic performance of elementary school students, while the latter only significantly predicts the academic performance of junior high school students. It is also worth noting that mother's education level is the only factor in the student's family background that has a significant negative impact on the pupil's academic achievement while other students' family background factors have a positive effect.

\section{Discussion}

\section{"Frequent" Housework Appears to be Positively Relat- ed to Student Academic Performance.}

The study uses the OLS regression model to make regression analysis on the various factors affecting student performance, and follows this with CEM matching to control for possible errors caused by sample selection bias. The matching results show that frequent participation in housework has a significant positive impact on the academic achievements of primary and junior high school students, but a difference exists between elementary school students and junior high school students. This result is mutually confirmed with the researches of Wang (Wang \& Xu, 2020), Gu (Gu, 2021), Fang (Fang \& Cao, 2021) and others. But actually, we don't know what "frequent" means in terms of hours, this result is based on our own criteria for dividing this frequency of housework participating. And maybe extreme amounts of housework participation might be detrimental. Fang's research also shows that the demarcation point is one hour as for the effect of housework on junior high school students' academic performance. 
Table 5. Regression Results after Weighted Coarsened Exact Matching (Dependent Variable: Academic Performance).

\begin{tabular}{|c|c|c|}
\hline & Primary School & Junior High School \\
\hline \multirow[t]{2}{*}{ Housework Participation Freq. } & $12.178^{\star * *}$ & $1.272^{\star *}$ \\
\hline & $(0.620)$ & $(0.540)$ \\
\hline \multirow[t]{2}{*}{ Gender } & $-5.694^{\star * *}$ & $-7.616^{\star \star \star}$ \\
\hline & $(0.591)$ & $(0.549)$ \\
\hline \multirow[t]{2}{*}{ Only-Child } & $15.219^{\star \star \star}$ & $9.273^{\star \star *}$ \\
\hline & $(0.696)$ & $(0.609)$ \\
\hline \multirow{2}{*}{ Urban / Rural Area } & $5.147^{\star \star \star}$ & $3.519^{\star \star \star}$ \\
\hline & $(0.764)$ & $(0.650)$ \\
\hline \multirow[t]{2}{*}{ Central Region Of Jiangsu } & $19.331^{* \star *}$ & $5.084^{* \star *}$ \\
\hline & $(1.234)$ & $(0.994)$ \\
\hline \multirow[t]{2}{*}{ Southern Region Of Jiangsu } & $6.135^{\star \star \star}$ & $-2.639^{* \star *}$ \\
\hline & $(0.834)$ & $(0.773)$ \\
\hline \multirow[t]{2}{*}{ Father's Education } & $4.239^{\star \star \star}$ & $4.316^{\text {***}}$ \\
\hline & $(0.220)$ & $(0.207)$ \\
\hline \multirow[t]{2}{*}{ Mother's Education } & $-1.456^{* \star *}$ & $0.762^{\star \star *}$ \\
\hline & $(0.209)$ & $(0.216)$ \\
\hline \multirow[t]{2}{*}{ Father's Occupation } & 0.009 & $0.095^{\star \star \star}$ \\
\hline & $(0.021)$ & $(0.023)$ \\
\hline \multirow[t]{2}{*}{ Mother's Occupation } & $0.078^{\star \star \star}$ & $0.117^{\star \star \star}$ \\
\hline & $(0.018)$ & $(0.020)$ \\
\hline \multirow[t]{2}{*}{ Family's Economic Status } & $75.963^{\star \star \star}$ & $59.698^{* \star *}$ \\
\hline & $(3.406)$ & $(3.062)$ \\
\hline \multirow[t]{2}{*}{ On/Off Campus } & -9.135 & $12.369^{* * *}$ \\
\hline & $(6.143)$ & $(1.028)$ \\
\hline \multirow[t]{2}{*}{ Academic Burden } & $4.020^{\star \star \star}$ & $3.564^{\star \star \star}$ \\
\hline & $(0.228)$ & $(0.183)$ \\
\hline \multirow[t]{2}{*}{ Constant } & $422.436^{\star \star \star}$ & $405.332^{* \star \star}$ \\
\hline & $(1.627)$ & $(1.684)$ \\
\hline Sample Size & 22,909 & 41,184 \\
\hline Adjusted $\mathrm{R}^{2}$ & 0.255 & 0.151 \\
\hline $\mathrm{F}$ & 603.47 & 563.77 \\
\hline
\end{tabular}

Doing housework more than one hour will have a negative impact on students' academic achievement (Fang \& Cao, 2021). This is also a good area for further research.

Based on our results, the reason why housework is conducive to the improvement of academic performance is that doing housework may affect the development of students' cognitive abilities such as thinking, logic and problem solving. Primary school students, for instance, may rely more on perceptual experience to complete learning tasks (Schmidt et al., 2019). Housework may thus help them understand what they have learned more concretely through hands-on practice (Anna, 2017). For junior high school 
Table 6. Binary Logistics Regression Results (Dependent Variable: The Frequency of Participation in Housework).

\begin{tabular}{|c|c|c|c|c|c|c|c|c|c|c|c|c|}
\hline & \multicolumn{6}{|c|}{ Primary School } & \multicolumn{6}{|c|}{ Junior High School } \\
\hline & B & $\mathbf{T}$ & $\mathbf{P}$ & OR & $95 \% \mathrm{Cl}$ & & $\mathbf{B}$ & $\mathbf{T}$ & $\mathbf{P}$ & OR & $95 \% \mathrm{Cl}$ & \\
\hline Gender & $\overline{0.135}$ & -8.221 & 0.000 & 0.874 & $-\overline{0.167}$ & $\overline{-}-103$ & $\underset{\star \star \star *}{0.273}$ & 19.761 & 0.000 & 1.314 & 0.246 & 0.300 \\
\hline $\begin{array}{l}\text { Only- } \\
\text { Child }\end{array}$ & $\bar{c}_{* \star \star} 0.081$ & -4.673 & 0.000 & 0.922 & $\overline{0}-115$ & $-\overline{0.047}$ & $\bar{x}_{* \star *} 0.213$ & - & 0.000 & 0.808 & $-\overline{0.242}$ & $-\overline{0.185}$ \\
\hline $\begin{array}{l}\text { Urban / } \\
\text { Rural } \\
\text { Area }\end{array}$ & $\overline{-}-022$ & -1.122 & 0.262 & 0.979 & $\overline{0} .060$ & 0.016 & $\begin{array}{l}- \\
0.125 \\
\star \star \star\end{array}$ & -7.822 & 0.000 & 0.882 & $\overline{-}-160$ & - \\
\hline $\begin{array}{l}\text { Central } \\
\text { Region } \\
\text { of } \\
\text { Jiangsu }\end{array}$ & 0.056 & 2.061 & 0.039 & 1.058 & 0.003 & 0.109 & $\begin{array}{l}0.180 \\
\star \star \star\end{array}$ & 7.904 & 0.000 & 1.197 & 0.135 & 0.224 \\
\hline $\begin{array}{l}\text { Southern } \\
\text { Region } \\
\text { of } \\
\text { Jiangsu } \\
\end{array}$ & $\begin{array}{l}- \\
0.085\end{array}$ & -4.070 & 0.000 & 0.918 & $\overline{-} .126$ & $\overline{0}-044$ & $\overline{-}_{\star \star \star} .210$ & - & 0.000 & 0.813 & $\overline{0} .242$ & $\begin{array}{l}- \\
0.171\end{array}$ \\
\hline $\begin{array}{l}\text { Father's } \\
\text { School- } \\
\text { ing } \\
\text { Years }\end{array}$ & $\underset{* * *}{0.023}$ & 6.272 & 0.000 & 1.023 & 0.016 & 0.030 & $\underbrace{-}_{\star \star \star} 0.016$ & -4.395 & 0.000 & 0.984 & $\overline{0} 023$ & 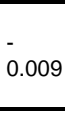 \\
\hline $\begin{array}{l}\text { Mother's } \\
\text { School- } \\
\text { ing } \\
\text { Years } \\
\end{array}$ & $\underset{* * *}{0.019}$ & 5.355 & 0.000 & 1.018 & 0.012 & 0.025 & 0.012 & 3.328 & 0.001 & 1.012 & 0.005 & 0.020 \\
\hline $\begin{array}{l}\text { Father's } \\
\text { Occupa- } \\
\text { tion }\end{array}$ & $\begin{array}{l}0.001 \\
*\end{array}$ & 1.821 & 0.069 & 1.001 & $\overline{0} .000$ & 0.002 & $\begin{array}{l}- \\
0.004 \\
\star \star \star\end{array}$ & -9.263 & 0.000 & 0.996 & $\overline{0} .005$ & - \\
\hline $\begin{array}{l}\text { Mother's } \\
\text { Occupa- } \\
\text { tion }\end{array}$ & $\underset{* \star *}{0.001}$ & 2.912 & 0.004 & 1.001 & 0.000 & 0.002 & 0.001 & 1.736 & 0.083 & 1.000 & $\overline{-}-000$ & 0.001 \\
\hline $\begin{array}{l}\text { Family's } \\
\text { Econom- } \\
\text { ic } \\
\text { Status }\end{array}$ & 0.098 & 1.495 & 0.135 & 1.103 & $\overline{0} .031$ & 0.228 & $\operatorname{l}_{\star \star \star}^{-} .166$ & -2.808 & 0.005 & 0.847 & $\overline{0}-282$ & - \\
\hline $\begin{array}{l}\text { On/Off } \\
\text { Campus }\end{array}$ & 0.016 & 0.312 & 0.755 & 1.016 & 0.085 & 0.117 & $\begin{array}{l}0.231 \\
\star \star *\end{array}$ & 10.411 & 0.000 & 1.260 & 0.188 & 0.275 \\
\hline $\begin{array}{l}\text { Academ- } \\
\text { ic } \\
\text { Burden }\end{array}$ & $\begin{array}{l}- \\
0.163 \\
* \star \star\end{array}$ & - 32.328 & 0.000 & 0.850 & $\overline{0} .173$ & 0.153 & $\underbrace{-}_{\star \star \star} 0.072$ & 19.139 & 0.000 & 0.930 & 0.080 & - \\
\hline
\end{tabular}

students (who have more difficulties in schoolwork and more pressure from academic competition), the academic impact of participation in housework appears to involve a more complicated mechanism, so there may be no simple linear positive correlation between the two variables. Our findings lend confidence however to the assumption that "frequent" housework will not hurt their academic performance.

\section{Primary and Junior High School Students' Participa- tion in Housework may be Insufficient, as the Burden of Schoolwork has a Significant "Crowding Out" Effect On Housework Participation}


Based on the 2020 Monitoring of Students' Academic Quality in Basic Education in Jiangsu Province, the study found that more than $50 \%$ of junior high school students and about $30 \%$ of elementary school students in Jiangsu Province did not often participate in doing housework, leading one to suspect that their engagement in housework may be insufficient, especially junior high school students. What are the factors that hinder elementary and junior high school students from participating in housework? By using the frequency of participation in housework as the dependent variable, and the relevant influencing factors as the independent variables, we construct a binary logistics model, and get the regression results in Table 6. This result clearly shows that for both primary and junior high school students, excessive academic burden is the key factor to prevent the students from doing much housework. There is a significant negative correlation between the schoolwork burden of students and their engagement in housework. This means that the heavier the schoolwork burden, the less time students can spend on housework, therefore the schoolwork burden has a significant "crowding out" effect on housework participation.

\section{Other Factors Affecting Students' Participation in Housework}

Our analyses suggest that factors such as gender, only-child, region, urban and rural areas, and family background all have an impact on primary and junior high school students' housework participation and academic performance. Among these, the influence of father's education level on children's housework participation and academic performance is quite thought-provoking. The above results show that, for primary school students, the higher the father's education level and occupation, the higher primary school students' frequency of participation in housework, but for junior high school students, the higher the father's education level and occupation, the lower the frequency of participation in housework. We believe that it may precisely reflect the current status of the father's role in family education. On one hand, a large number of studies have found that there is still a widespread phenomenon in Chinese families of "men managing external affairs and women internal", which means that in family education, fathers often play the role of providing more generous social resources to the family through "outside" work and social activities. On the other hand, because the academic pressure at the junior high school stage is much greater than that at the primary school stage, in the sequence of family resource input, most families tend to focus on aspects that are conducive to the improvement of academic performance at the junior high school stage. In this process, fathers with higher academic qualifications and higher professional levels tend to access more social capital to increase time and energy investment in children and academic performance, thereby forming a "crowding out" effect on housework education. This will undoubtedly have an adverse effect on housework participation in the junior high school stage. In short, the analysis results in Table 6 show that from primary school to junior high school, the change in the focus of family social resource input is more accomplished by the change of the father's role. In the junior high school, the father (who represents family resources) turns more preference towards improving children's academic performance, which has a negative impact on children's housework 
participation (Yao \& Chen, 2020; Wang, Zhao \& Meng, 2015; Zhao, Wang \& Liu, 2013).

\section{Research Limitations and Prospects}

Housework is an important way to shape personality as well as character, and boost the all-round development of primary and junior high school students. In fact, whether housework can improve academic performance or not, it should be given more attention and appreciation. The focus in this study has been put on the impact of housework on academic performance, for the reason that only a few studies on this issue have been made in China. Besides, if the positive effect of housework on academic performance can be shown, the worries of schools and parents will be relieved, and more parents may realize the importance and value of housework and be willing to let their children to perform it. As far as the present research is concerned, the impact of housework on students' character and personality is not involved, and the discussion on how housework can influence students' development has not been fully investigated. It is argued that this may be more important than the relationship between housework and academic performance, which should be addressed in future research.

\section{Conclusion and Suggestion}

The conclusions of this study are more robust and accurate because more detailed and larger scientific data were employed by CEM. The results have shown that the current situation of Chinese primary and junior high school students' participation in housework is not ideal, with $23.1 \%$ of elementary school students and $53.7 \%$ of junior high school students participating in housework infrequently. In terms of the impact of housework on academic performance, after Coarsened Exact matching, if the students had the similar individual characteristics, family background, and the environment, then primary school students who frequently participate in housework had an average academic score of 12.178 points higher than those who do not often participate in housework; the academic performance of junior high school students was about 1.272 points higher. This shows that frequent participation in housework has a positive effect on the improvement of students' academic performance. Further analysis showed that the student's academic burden had an obvious "crowding out" effect on their participation in housework, and during which process, parents' anxiety about schoolwork is a key factor affecting their children's participation in housework.

Based on the above findings, we hold that to further strengthen the housework education of primary and secondary school students, joint efforts should be made by the society, schools, and parents together to improve students' personalities through housework education and thus achieve the overall development of students.

\section{Strengthen Publicity and Guidance to Enhance Peo- ple's Awareness of the Importance of Housework Edu- cation.}


On the one hand, researchers need to provide more reliable evidence to clarify the influencing factors, mechanism of action, and effective implementation path of housework education. On the other hand, the education authorities and schools should further increase publicity and guidance with various channels of communication to clarify the importance of housework education, and help parents raise their awareness of housework education, reduce or eliminate their excessive academic anxiety, and thus actively implement family housework education. In this process, great attention should be paid to how to transfer the academic research results, and guide the parents to change their education concepts and educational models with scientific evidence.

\section{Reduce the Burden of Schoolwork Effectively and Re- lieve its Squeeze on Housework.}

A major problem found in current family's education on hard working spirit was that the overburden of schoolwork would encroach on the time of doing housework. To solve this problem, educational viewpoints should be changed, moreover, how to reduce the excessive academic burden of students effectively is also a key issue. This means that schools should improve teaching efficiency, strengthen homework management, cut down ineffective or noneffective repetitive exercises, and explore the assignment of practical homework to give back after-class time to the students. On the government level, it must reinforce the management of after-school tutoring classes, take actions to combat irregular school-running behaviors, which is focused on blowing up excessive anxiety, and guide teaching and training institutions to offer students more practical housework education courses in order to help schools and families make progress in housework education and promote students' overall development.

\section{Make Full Use of Various Education on Hard Working Spirit Resources to Provide Children With Diversified Opportunities of Housework Education.}

Chinese famous educator Xingzhi Tao once said, "The life you live is the education you receive. If you live a lavish life like a young master, even if you read books about hard working every day, you are not considered to be educated by hard working." (Dong, 1991) Only by practicing the life of housework can we implement housework education truly and effectively. Because life covers a wide range of areas, housework education requires the joint efforts of families, schools, and society to provide students with life-oriented, experiential, and interesting housework education resources and opportunities to take part in housework while creating a social atmosphere in which housework is glorious. In this process, more bases should be constructed to experience housework and do social practice by the government and society, and more housework courses should be set up by the school. In addition, students should be encouraged to engage in more housework by the family. Only with the concerted efforts of all parties can we offer more chances of housework education to primary and secondary school students. 


\section{References}

Anna, E. (2017). The dewey school: The laboratory school of the university of Chicago 1896-1903.Taylor and Francis, 2017. DOI: https://doi.org/10.4324/9781315131733

Bao, Z.L. (2013). An empirical study on the status quo of labor education for young students. Educational Exploration, 2013(8):9193. DOI: https://doi.org/10.3969/j.issn.10020845.2013.08.039

Blair, S. L. (1992). Adolescence: Children's participation in household labor: Child socialization versus the need for household labor. Journal of Youth, 21(2):241-258. DOI: https://doi.org/10.1007/BF01537339

Chen, C. J., \& Gu, X. Q. (2019). The impact of online games on students' academic literacy and social integration: An analysis based on the PISA2015 test data from four provinces and cities in China. Open Education Research, 25(5):73-87. DOI:

https://doi.org/10.13966/j.cnki.kfjyyj.2019.0 $\underline{5.008}$

Chen, F.Z., \& Lu, X.D. (2021). Inclination, knowledge and ability: Re-exploration of the relationship between labor education, moral education and intellectual education. Educational Academic Monthly, 2021(3):3-11+54. DOI:

\section{https://doi.org/10.16477/j.cnki.issn1674-} 2311.2021.03.001

Dong, B.L. (1991). Selected works on education by Tao Xingzhi. Selected Works on Education by Tao Xingzhi, 1991, 390.

Fang, C.C., \& Cao, L.Z. (2021). The influence of family labor on the ability development of junior high school students-An empirical study based on CEPS Data. Journal of Educational Science of Hunan Normal University, 20(2):56-63+89. DOI:

https://doi.org/10.19503/j.cnki.16716124.2021.02.008

Fu, X.F., \& Zhou, L. (2005). Labor technical education in German basic education. Comparative Education Research, 2005(2):35-40. DOI: https://doi.org/10.3969/j.issn.10037667.2005.02.007

Goh, E., \& Kuczynski, L. (2014) She is too young for these chores' - Is housework taking a back seat in urban Chinese childhood?
Children Society, 28(4). DOI:

https://doi.org/10.1111/j.1099-

0860.2012.00470.x

Goodnow, S. (1989). Children's household work: Task differences, styles of assignment, and links to family relationships. Journal of Applied Developmental Psychology, 10(2):209226. DOI: https://doi.org/10.1016/01933973(89)90005-1

$\mathrm{Gu}, \mathrm{S}$. (2021). A four-dimensional examination of labor education in the new era. Journal of Dalian University of Technology (Social Science Edition), 42(3):110-115.

$\mathrm{Gu}$, X.L. (2018). How to carry out labor education in American schools. People's Education, 2018(21):77-80.

He, D.C. (2009). Preface to "important educational documents of the People's Republic of China". The 20th Anniversary of the Publication of "Research on History of Education" and the Seminar on the Sixty Years of Research on History of Education in China, 2015:114-115.

Huang, J. (2004). Understanding and Suggestions on Labor Education. Journal of Jiangsu Education Institute (Social Science Edition), 2004(5):17-22.

Iacus, S.M., King, G., \& Porro, G. (2011). Multivariate matching methods that are monotonic imbalance bounding. Journal of the American Statistical Association, 106(493):345-361. DOI: https://doi.org/10.1198/jasa.2011.tm09599

Iacus, S.M., King, G., \& Porro, G. (2012). Causal inference without balance checking: coarsened exact matching. Political Analysis, 20(1):1-24. DOI:

https://doi.org/10.1093/pan/mpr013

Jin, Y.J. (2001). Imputation adjustment of missing data. Mathematical Statistics and Management, 2001(6):47-53. DOI: https://doi.org/10.13860/j.cnki.sltj.2001.06.0 $\underline{12}$

Lao, K.S. (1998). New exploration of the combination of education and production labor. New exploration of the combination of education and production labor, 1-4.

Li, C.L. (2005). The prestige stratification of contemporary Chinese society: Occupational 
Wang et al. Does Housework Help Improve Academic Performance?

prestige and socioeconomic status index measurement. Sociological Research, 2005(2):74-102+244. DOI: https://doi.org/10.19934/j.cnki.shxyj.2005.0 2.004

Li, H.F. (1983). The Guarantee of Educational Success: The cooperation of schools, families, and society-The sixth special topic introduction to elementary and secondary education in the soviet union. Foreign Elementary and Secondary Education, 1983(2):1015.

Li, K., \& Qu, X. (2018). The historical evolution and reflection of labor education in the party's educational policy since 1949. Journal of Education, 14(5):63-72. DOI: https://doi.org/10.14082/j.cnki.1673$\underline{1298.2018 .05 .008}$

Mirko, S., Benzing, V., Wallman-Jones, A., Mavilidi, M.F., Lubans, D.R., \& Paas F. (2019). Embodied learning in the classroom: Effects on primary school children's attention and foreign language vocabulary learning. Psychology of Sport \& Exercise. 43. DOI:

https://doi.org/10.1016/i.psychsport.2018.12. 017

Pang, X.S. (2004). Discussion on related issues in missing data processing. Statistics and Information Forum, 2004(5):29-32. DOI: https://doi.org/10.3969/j.issn.10073116.2004.05.007

Rosenbaum, P.R., \& Rubin, D.B. (1983). The central role of the propensity score in observational studies for causal effects.

Biometrika, 70(1):41-55. DOI: https://doi.org/10.1017/cbo9780511810725. $\underline{016}$

Tan, R.X. (2019). Spain: Housework can promote the development of children's creativity. People's Education, 2019(1):9.

Tang, G.Q. (2009). Freedom and harmony-A study on Cai Yuanpei's view of "Five Educations Simultaneously”. Education Research Monthly, 2009(1):38-42+55. DOI: https://doi.org/10.16477/j.cnki.issn16742311.2009 .01 .012

Vaillant George E. (2012). Triumphs of experience: The men of the Harvard grant study. Harvard University Press, 2012:92-117.
Wang, F., \& Xu, J.C. (2020). Investigation and research on the implementation status of labor education in universities, middle schools and primary schools. Curriculum, Textbook, Teaching Method, 40(2):12-19. DOI: https://doi.org/10.19877/j.cnki.kcjcjf.2020.0 2.003

Wang, L.F., \& Chen, C.F. (2015). Extracurricular life of primary and middle school students and its relationship with subjective well-being. Chinese School Health, 36(3):390-393+396.

Wang, M.F., Zhao, J.X., \& Meng, Q.X. (2015). The relationship between mother's academic control and children's academic and emotional adaptation: laboratory observation research. The 13th Annual Conference of the Developmental Psychology Professional Committee of the Chinese Psychological Association, 46.

Xiong, Z.W. (2021). The practice of localization of labor education in modern western countries: Content, experience and enlightenment: the exploration of Xianghu Normal University. Educational Academic Monthly, 2021(3):27-33. DOI: https://doi.org/10.16477/j.cnki.issn16742311.2021.03.004

Yao, S., \& Chen, J.J. (2020). How does the mother's educational background affect the children's years of education: An empirical analysis based on CLDS2016. Journal of Huazhong University of Science and Technology (Social Science Edition), 34(3):87-96. DOI:

https://doi.org/10.16477/j.cnki.issn16742311.2021.03.002

Yin, H. (2021). The value of labor education in craftsman culture and its realization. Educational Academic Monthly, 2021(3):12-17.

Yuan, L.P., \& Li, J.X. (2021). Knowledge graph and future prospects of labor education research in my country. Educational Academic Monthly, 2021(3):18-26.

Zhang, M., \& Yuan, H. (1997). PauTa criterion and outlier elimination. Journal of Zhengzhou University of Technology, (01), 87-91.

Zhao, J.X., Wang, M F., \& Liu, L. (2013). The relationship between mothers' academic participation and children's academic performance: the mediating role of children's abil- 
Wang et al. Does Housework Help Improve Academic Performance?

ity theory. Psychology and the improvement ference on Psychology, 2.

of innovative ability-The 16th National Con-

Received: 29 November 2021

Revised: 08 December 2021

Accepted: 29 December 2021 